Published as: Kate Macdonald and Shelley Marshall, "Social governance in a global economy: Introduction to an evolving agenda", in Macdonald, Kate and Marshall, Shelley (eds), Fair Trade, Corporate Accountability and Beyond: Experiments in Globalizing Justice, Ashgate Publishing, Aldershot (2010): pp.3-36

\title{
Social governance in a global economy: introduction to an evolving agenda
}

\author{
Kate Macdonald and Shelley Marshall ${ }^{\neq}$
}

\section{Introduction}

In January 2007, the UK arm of the corporate giant McDonalds announced that it would be sourcing all its coffee with a certification from the US-based non-profit organisation Rainforest Alliance. "Today's announcement ... means we can offer our customers great tasting coffee that benefits coffee growers, their communities and the environment," declared Steve Easterbrook, President and CEO of McDonald's UK, in the statement accompanying the launch of the new initiative. ${ }^{1}$ Around the same time, the then CEO of global retailing giant Walmart - the reigning poster-child of global corporate abuse in the minds of many - began to embrace the language of environmental and social responsibility, littering speeches and public statements with pronouncements about the company's newfound commitment to 'Doing Well by Doing Good', which involved introduction of several environmental initiatives and

\footnotetext{
${ }^{*}$ The authors would like to thank Kamillea Aghtan for her wonderful research and editing assistance for this volume.

${ }^{1}$ http://www.rainforest-alliance.org/news.cfm?id=mcdonalds, accessed 7 April 2009.
} 
incorporation of a range of 'ethical' products - including Fairtrade certified and organic ranges of coffee - into its 'Sam’s Range’ of premium products. ${ }^{2}$

Such announcements have been met with scepticism among many who have come to associate corporate brands such as Walmart and McDonalds more closely with 'McJobs', 'Always Low Wages' or the destruction of Brazilian rainforest to feed the huge demand for beef burgers, than with agendas of social and environmental responsibility. Despite being the subject of great controversy, the embrace of such new strategies by major businesses symbolises a huge shift in ideas around the responsibilities of business that has occurred in the last 10 to fifteen years.

Indeed, such cases of large global corporations scrambling to climb aboard the ‘corporate social responsibility' and 'Fairtrade' wagons are by no means isolated examples. All around the world - but particularly in core centres of the industrialised global north - major global corporations have been searching for new ways through which principles of corporate social responsibility can be incorporated into the way they do business; or, as some would suggest, at the very least into the way they do their public relations and marketing. Putting aside questions regarding the strengths or weaknesses of these instruments, the quick and steady growth of companies that have adopted CSR mechanisms has been impressive. By the end of 2007 the UN Global Compact, the world's largest CSR initiative, had approximately 3,600 participating companies, out of what UNCTAD estimated to be a total of 78,000 Transnational Corporations (TNCs) and 780,000 affiliates operating worldwide (UNCTAD 2007, cited by Utting in this volume, Chapter 9). Increased recognition of the importance of CSR is also reflected in rising government interest, especially in Europe, expressed

\footnotetext{
${ }^{2}$ http://walmartstores.com/FactsNews/NewsRoom/, accessed 7 April 2009.
} 
for example through intergovernmental initiatives such as the OECD Guidelines for Multinational Corporations, and the passing of 'ethical sourcing' legislation in a number of jurisdictions (McBarnet et al. 2007).

These developments have broadly mirrored a parallel rise and expansion in the scale and support for ethical initiatives such as the Fairtrade system that operate within the civic domain. Some such initiatives have provided institutional vehicles through which growing constituencies of concerned coffee drinkers, consumers, investors and citizens can give direct expression to their concerns regarding the conditions under which goods are produced. Others have emerged to support and/or demand responsible corporate action, as well as to promote more far-reaching agendas of justice in the domains of production and trade. In short, over the course of the last decade and a half, agendas of ethical trade and consumption together with associated agendas of corporate responsibility and accountability have been expanding and consolidating across both 'barricades and boardrooms' throughout the world (Bendell 2004).

It would be a mistake to overstate the extent or impact of this shifting agenda with respect to mainstream corporate practice. As a proportion of international corporate numbers, very few businesses have adopted practices associated with corporate responsibility such as social auditing, joining established corporate responsibility mechanisms such as the UN Global Compact or even creating their own 'corporate codes of conduct'. Furthermore, the agenda's impact on business practices associated with labour standards or environmental sustainability has in many cases been very limited. In the same period in which corporate responsibility has gained ideational leverage, real wages for many vulnerable workers have continued to fall. In December 2007, Neil Kearney of the International Textile, Garment and Leather 
Workers' Federation noted that over the past 12 years real wages in the textiles sector have fallen by 25 per cent and working hours increased by 25 per cent (cited by Utting, Chapter 9). ${ }^{3}$ Instead of shrinking, as most labour economists expected, informality in working relations increased, placing great numbers of workers beyond the reach of legally enforceable standards (ILO 2002).

Regardless of such contradictions, there is little doubt that the many social movements campaigning for global social justice (a term we shall address in greater detail later in this chapter) have made some gains in the battle over ideas. Their success in shifting this contested 'ideational space' has, in turn, presented those opposing contemporary forms of corporate power with some challenging strategic dilemmas. As the corporate responsibility and fair trade agendas mature, they have been running aground against a seemingly intractable set of new problems, leading to increasing frustration, cynicism, and uncertainty about how to proceed. For example, the commercial success of fair trade has meant that Fairtrade Labelling Organisation (FLO) was recently faced with the dilemma of whether to license Nestlé, a company that has been the subject of a number of fierce social justice campaigns (see Hutchens in this volume; see also (Baby Milk Action 2009)). In such cases, popularity brings with it new strategic and moral quandaries. Other practical problems have resulted from the increasing complexity and pace of change within globally dispersed supply chains. New power brokers within supply chains are emerging who are willing to

\footnotetext{
${ }^{3}$ Presentations made at the International Labour Organization MultiForum 07: Better Business: Managing Labour Relations for Productivity and Growth, Geneva, 15-16 November 2007 and the European Union Conference on Corporate Social Responsibility: CSR at the Global Level: What Role for the EU?, Brussels, 7 December 2007.
} 
employ previously untried tactics as means of resisting pressure from corporate responsibility activists (see Maksimovic, Chapter 13 of this volume).

An even greater problem faced by activists, practitioners and policy makers is lack of clarity around foundational theoretical questions regarding the divisions of social and political responsibility between national governments and international institutions, and between public and private actors. Both the practical problems confronting emerging initiatives and these deeper theoretical questions that underpin them are the subject of the chapters in this collection.

It is the central contention of this book that the initiatives examined by contributing authors have in common a wish to see capitalism embedded in a set of norms that identify with discourses of '(global) social justice' of varying kinds. Such goals are fundamentally concerned with countering the perceived tendency towards the production of inequality and the commodification of labour relations associated with capitalist dynamics of accumulation. Some of the approaches examined in this book broadly accept the benefits of capitalism and are committed to working within the terms of the system. They aim at 'tweaking' it so as to share its benefits and promote more collaborative relations. Others seek a deeper transformation which would challenge the terms of the system in a number of ways. Our aim is to evaluate which strategies along such a spectrum have proven successful in relation to the promotion of social justice norms of varying kinds.

In this introductory chapter, we first outline the aims, scope and approach of the book, and its contribution to theoretical and empirical debates. We then set up our approach to understanding the problem as one of the disembedding of capitalism. We describe the shift from what has been broadly described as 'embedded liberalism' in the period following the end of World War II through the 'neoliberal' era and to the 
present, and then explore the ways in which governance initiatives of the kind examined in the chapters seek to embed an increasingly global capitalism in norms of social justice. There seem to be ever-expanding numbers and variants of governance initiatives of these kinds. To assist readers to navigate the more detailed case studies provided by contributing authors, this introductory chapter also provides a description of the main types of initiatives examined by the book. We situate variants of fair trade, corporate social responsibility and corporate accountability governance initiatives and associated activism within a collaborative/transformational spectrum.

In the final part of this chapter we lay out an evaluative framework through which the contributions of the initiatives to the embedding of social justice norms in the governance of global production and trading systems can be evaluated. 'Social justice' is an appealing and widely used term, especially among social movements. However, its meaning - particularly as a yardstick by which to evaluate the achievements of specific initiatives - is hazy. We specify what we mean by norms of (global) social justice, locating this account within both theoretical literature and broader public discourse surrounding this concept. We explain how the contribution of individual initiatives to social justice goals can be evaluated not only by documenting their direct impact on the rights of individuals, but also by assessing their impact on institutional change of more or less 'transformative' kinds. This evaluative framework then lays the basis for the synthesis and evaluation of these agendas as a whole which we present in the concluding chapter to this volume.

Aims, scope and approach of the book

The central driving motivation of this book a practical one - to address a question that has moved to the forefront of debate in recent years among both participants in and scholars of global political economy: How can production and trade within 
transnational supply chains be effectively governed so as to protect core human and social rights and advance broader principles of justice within a global economy?

In order to examine this core question, contributors study the potential role of a range of emerging state and non-state initiatives - broadly termed 'fair trade', ‘corporate social responsibility’ (CSR) and ‘corporate accountability’ initiatives within agricultural and industrial supply chains. These initiatives seek to promote agendas of global social justice of various kinds by developing non-state or mixed state-and-non-state instruments of public governance within global production systems. These 'initiatives' for global social justice often have a rather ambiguous status - falling neatly into neither of the established categories of 'social movements' or 'governance institutions'. Rather, characteristics of each combine in varying and often rather fluid and ambiguous ways, seeking at times to provide an institutional framework for regulating and governing global economic relationships in their own right, and at other times more closely resembling what we would traditionally conceive of as advocacy campaigns or social movements (Keck and Sikkink 1998; Tarrow 1994).

The book examines a broad range of such initiatives, varying in the extent to which they offer means of providing public governance functions in their own right, and/or operate primarily as vehicles of ideational and institutional change within other established sites of governance. Reflecting the book's central interest in the transformative potential of initiatives of different kinds, the structure of the book is organised around groupings or categories of such initiatives. Part I examines individual and civic action through fair trade. Part II examines CSR initiatives driven by responsible consumers and corporations. Part III broadly examines workers' activist campaigns as part of wider movements for worker empowerment and 
corporate accountability. Part IV examines initiatives that seek to strengthen and transform the role of the state.

With reference to emerging governance initiatives of these varying kinds, authors consider a number of more specific questions:

- What are the core problems of injustice or governance failure that these initiatives seek to respond to, and how are these evolving?

- How are emerging governance initiatives within the global economy themselves evolving through an ongoing process of experimentation and adaptation?

- What outcomes are such governance initiatives achieving, in relation to both direct facilitation of rights fulfilment, and also the promotion of institutional transformation to create the structural conditions for rights fulfilment at a broader and sustained level?

- What factors determine the relative success of different initiatives in promoting these outcomes?

In view of the eclectic nature of the collection - and of the theoretical and methodological approaches underpinning different contributions - we do not claim to offer systematic or comprehensive examination of these questions. Rather, we view these as the guiding questions providing an overarching coherence to the widely varying contributions to the volume; in the concluding chapter, we organise our reflections on lessons from the chapters around these questions, recognising also that such conclusions remain reflective and exploratory in nature. Our concluding analysis focuses in particular on evaluating the strengths and weaknesses of the differing initiatives, and seeking to identify key variables on which relative success appears to hinge. 
While there is much variation in the methodological and disciplinary approaches employed to explore these cases and questions, the approaches of contributing authors share a few distinctive characteristics which differ somewhat from those widely used within much established literature. Huge volumes of material have been produced examining issues of corporate responsibility, non state governance, global civil society and their relationship to questions of rights, justice and development in the context of globalisation, reflecting the huge upsurge of interest in such issues in recent years. However, the theoretical and methodological approaches through which such initiatives have been examined have tended to be highly fragmented along disciplinary lines, leading to a lack of synthesis and engagement along three important dividing lines.

First, there is a widespread lack of engagement between normative and empirical bodies of research, which has meant the evaluative criteria used to examine the 'effectiveness' of these initiatives tends to lack a well developed normative framework focused on rights and justice. There has also tended to be a lack of engagement between theoretical and applied study of these initiatives, particularly in relation to their governance dimensions. Finally, there has also been a disconnect between micro and macro perspectives, both theoretically and methodologically, meaning that locally informed evidence from specific contexts has been poorly synthesized with system level analysis. The fragmentation of existing research resulting from these divisions has also tended to work against the development of empirical analysis that examines the interactions between state, market and civic systems of regulation. 
Contribution to policy and theoretical debates

By exploring its central questions with reference to a broad range of contrasting empirical examples and from a range of disciplinary perspectives, the book seeks to contribute to contemporary policy and scholarly debates in several ways.

First, the book engages with debates focused on questioning the relative merits of broadly 'collaborative' (moderate) versus 'confrontational' (radical) approaches to tackling perceived injustice. Questions of this kind have often been considered by scholars of social movements and activist networks, as well as others within development, anthropology or industrial relations literatures concerned with questions of institutional design and social movement strategy (McAdam et al. 2001). Such questions are particularly important to those of our contributors concerned primarily with the practical question of what works in the design and operation of these kinds of initiatives, from the perspective of promoting global justice norms. Consideration of this first kind of question engages with debates surrounding the strategic difficulties faced by contemporary CSR, corporate accountability and fair trade movements as they attempt to consolidate what they have achieved over the past decades, and confront new challenges of responding to ongoing changes within a globalising political economy, and attempting to ratchet up established approaches.

A second set of questions, also very much focused on the question of 'what works' as a basis for promoting global justice norms within a globalising economy, relates to the design of the institutional instruments and mechanisms through which social regulation and governance takes place. Such questions have received particularly extensive treatment in the context of debates within governance and regulatory literatures. Debate has centred around issues such as the relative merits of voluntarist versus legal modes of regulation/governance (Kirton and Trebilcock 
2004), and exploration of how new regulatory techniques can be employed so as to combine softer, reflexive modes with command and control methods (McBarnet et al. 2007). Of particular interest for our purposes are debates that interrogate the relative merits of 'soft/voluntarist' versus 'hard/legal' modes of regulation; an issue that has preoccupied many regulatory scholars over the past decade at least (as we discuss further below). These questions have some relevance for the design of the initiatives themselves, but are also important for understanding the appropriate techniques through which governments can and should engage with these initiatives if the goal of promoting social justice norms within the global economy is to be effectively promoted.

Third, while the previous two sets of debates concern themselves primarily with 'what works' in a practical sense, another set of debates focuses on interpreting the significance of these initiatives from a broader systemic perspective. On one level these initiatives can be viewed as representing private initiatives through which individual consumers or firms express their individual norms and preferences via their consumption or business choices. A contrasting interpretation views these initiatives as part of a broader trend towards the invention of 'a new system of global governance' able to promote goals of social justice in a globalising economy, as some commentators have suggested (Haufler 2001; Ruggie 2003). Interpretation of such initiatives through this regulatory or governance lens has been particularly common among international relations and global governance scholars, and among those working within broader international and comparative political economy traditions, in which analysis of the 'embedding' of capitalist forms of market economy within norm-based institutions of social regulation has a long and intensely contested heritage. This question about the broader macro-institutional significance of these 
initiatives as new forms of social governance within a globalising capitalist economy sits in the background throughout this book, framing the analysis and providing a backdrop for thinking about the significance of the initiatives being examined. This question is also important from a practical perspective in so far as it aids understanding of what contribution initiatives of this kind can make to changing the broader institutional environment beyond the initiatives themselves.

While these three sets of debates have often emerged quite separately within theoretical debates structured around disciplinary divides, within policy and advocacy discourses they have tended to play out in closely intertwined ways, clustering roughly around two opposing 'images' of normative and strategic orientation towards goals of social and political change - one broadly 'collaborative' and the other more 'confrontational' in both objectives and strategies. Such differences in orientation have implications for the goals and strategies of individual initiatives, and for the way individual actors and initiatives interact with each other, and with governments and other actors within the wider global governance system (O'Brien 2000; O'Brien et al. 2000; Utting 2006).

At one side of this opposition is a cluster of approaches that seek to work 'within the terms of the system' (or 'within the grain') to bring about improved operation of the system to promote social justice outcomes. For example, a number of NGOs regard corporate responsibility programs and supply chain governance systems as offering potential means of strengthening existing social and labour standards within global production systems. Such 'collaborative' sympathisers point to examples of modest but positive achievements of many such initiatives, and highlight the potentially constructive ways in which NGO participation can strengthen the operation of such schemes (Doh 2006; Vitt 2007). This cluster of approaches has 
tended to embrace greater measures of voluntarism, collaborative and nonconfrontational modes of campaigning and corporate engagement, and more broadly a desire to work within the terms of market capitalism to bring about change - accepting the legitimacy of this system's basic constitutive terms while seeking to regulate and compensate for its excesses.

On the other side of the opposition are those initiatives that seek to 'change the terms of the system', identifying themselves broadly as working 'against the grain' to bring about deeper forms of systemic transformation. Those endorsing such deeper and more transformative modalities of interaction often regard NGO and corporate collaboration as providing protective shields of legitimacy (or 'fig-leaves') to corporations, which they view as disproportionate to the achievements of such corporate schemes. 'Confrontational' groups therefore view such collaboration as potentially damaging to the prospects of long term change, since it tends to undermine some of the de-legitimising pressure that they strive to place on corporations. Within this strategic cluster, sympathy for a relatively confrontational approach to the design and operation of the governance initiatives themselves has tended to be associated with support for reasonably expansive systems of norm-based regulation of market capitalism in which prevailing social power relations and legitimising ideas are more extensively resisted; such a relatively confrontational orientation has also been associated with a preference for legal rather than voluntary approaches to economic regulation.

What is centrally at stake in these debates is the extent to which the objectives and strategies of given initiatives challenge the prevailing 'rules of the game', in the sense of distributions of roles, responsibilities and power between classes of actors, all of which interact to condition the kinds of normative values and outcomes supported 
by the system's operation. Those on opposing sides of the debate differ in their assessment of the extent to which norms of social justice can be governed 'within the terms' of the capitalist system. Both sides tend to regard capitalist systems of production and trade as incorporating inherent tendencies that contribute to dynamics of inequality (as we discuss further below); where they differ is on the question of whether these can be effectively tamed via familiar regulatory and redistributive techniques, or whether deeper constitutive changes are required to challenge the underlying norms, incentives and power relations in which capitalist systems of production and trade are grounded.

These opposing 'images' do not map cleanly onto classifications of all the initiatives we examine, and in this sense we regard them has having a heuristic value (as 'ideal types') as much as a descriptive value. Nevertheless, these images continue to play an important role in a practical sense in helping actors to navigate the array of interacting and often competing initiatives, since participants within initiatives often self-identify explicitly or implicitly in terms of these underlying oppositions, and in many cases also interpret the role of other initiatives through the lens of this kind of typological spectrum.

\section{Understanding the problem: the disembedding of capitalism}

One of the first major analytic tasks of this book is to make sense of perceived injustices in globalised labour, production and trading regimes by examining the evolving relationship between globalising systems of liberal market economic relations, and systems of social regulation concerned with what we define below as broadly ‘social justice’ oriented norms, both within and beyond nation states. 
In the following sections we first define the concept of (dis)embedding before discussing the ways in which governance deficits have arisen and evolved in recent years in developed and developing country contexts.

\section{The concept of (dis)embedding}

The concept of (dis)embedding, which has been employed in a variety of ways, provides a useful framework for understanding the operation of CSR, fair trade and corporate responsibility movements as attempts to re-embed capitalism in social justice norms. The term has been widely used by scholars who seek to understand dynamics of co-dependence between social institutions of different kinds (social, political and economic), and the apparent clustering of such patterns of inter-twined social relations in particular geographical locations. ${ }^{4}$ Understood in this sense, the concept of 'embedding' assists analysis of how markets, supply chains and transnational business systems are constituted, influenced and regulated by actors and

\footnotetext{
${ }^{4}$ The former meaning is associated with economic sociologists such as (Granovetter 1985), for whom the concept of embedding is primarily concerned with understanding "how economic action is embedded in structures of social relations, in modern industrial society”. In the latter sense, (Giddens 1990, p.21) uses the term 'disembedding' to refer to “the 'lifting out' of social relations from local contexts of interaction and their restructuring across indefinite spans of time-space”. The latter approach is also reflected in the use of the term by some economic geographers, who "spatialis[e] the notion of embeddedness, which had originally been developed by economic sociologists to stress the ways in which economic processes are grounded in social relations”. (Cumbers et al. 2003, p.328) (Amin and Thrift, 1994, Keeble et al 1999, Morgan 1997). See also (Sassen 2002, p.96; Sassen 2003, p.15).
} 
institutions beyond the supply chain, encompassing states, local and global markets, and more diffuse complexes of territorially bounded social institutions. ${ }^{5}$

The concept tends to take on a more critical meaning to the extent that such analysis is linked to a more systemic account of modes of embedding in particular phases or forms of capitalism, as for example in Polanyi’s classic work, The Great Transformation (Polanyi 1944); in this book, Polanyi analysed the transition Europe experienced from a virtually unregulated market in the $19^{\text {th }}$ century through a 'great transformation' in which the market was subordinated once again to the social norms and controls in which he suggested it had traditionally been embedded. Jessop (Jessop 2001b) likewise explores different forms of social embeddedness within contemporary capitalism, seeking to understand how the coupling of wider social institutions with those of market (capitalist) economic systems assists to sustain and reproduce the capitalist system as a whole. ${ }^{6}$

In this critical sense, which is the way we mainly use the term, the concept of 'embedding' takes on a distinctly normative meaning, in which social embedding is regarded as a process that aspires to subordinate private relations of power operating through markets to "social values that we can defend ethically", in Amartya Sen's recent words (Sen 2009). On this view, there are two distinct grounds on which the

\footnotetext{
${ }^{5}$ The concept in this sense need not be limited to concrete 'institutional forms', but can also be understood as encompassing much broader and more nebulous influences, such as those (Stewart, p.27) characterises as the "macro-environment" which "encompasses the norms and political economy prevalent in a society - that is it includes the manifold influences - economic, political and social - to which individuals and groups are subject by the environment in which they operate.”

${ }^{6}$ (Jessop 2001b) draws on Polanyi, as well as on the French regulation approach and system theoretical accounts, all of which are interested in various ways in the social embedding of capitalism.
} 
power relations within a capitalist economy could be said to be 'disembedded'. First, such power relations may not be effectively regulated by a consistent and explicit set of social norms of any kind. Second, such a charge may be based in a more normative claim, that the norms through which such regulation is taking place cannot be ethically justified. In order to operationalise the concept of (dis)embedding as an evaluative tool, analysis therefore needs to be anchored in both an explicit account of ethically defensible norms defining the principles on the basis of which capitalism should be regulated, and an institutional account of what it would mean for these to be effectively and consistently applied.

The evaluative analysis presented in this book is anchored in the institutional dimension with reference to the capacity of political governance arrangements (involving state as well as non-state modalities) to effectively regulate a globalising capitalist economy on a consistent and principled basis. At the normative level, our evaluation is anchored with reference to a particular set of social justice norms (elaborated further below), which define the principled basis on which power relations and inequalities of certain kinds may be considered illegitimate, and the claim of governance initiatives to legitimately intervene to protect and promote specified rights and duties thereby justified.

\section{Dynamics of disembedding within a capitalist market economy}

It is useful to begin by laying out some of the key assumptions and propositions that underpin many critical analyses of 'disembedding' within capitalist systems of market economy. While definitions of 'capitalism' vary widely, we can point towards a number of core characteristics that a broad range of critical scholars identify with a capitalist market system (Polanyi 1944; Wood 2002). Of greatest relevance to our 
interest in the structure and dynamics of global labour, production and trading regimes are: (a) capitalist modes of production involving the extraction of surplus from labour; (b) market exchange; (c) geographically clustered dynamics of accumulation.

Each of these tendencies has been claimed to be associated with normatively problematic social outcomes of specific kinds. First, commodification of labour relations are regarded as creating the conditions under which labour (particularly under conditions of surplus labour) has weak bargaining power and is likely to be 'exploited' in relation to both wages and working conditions. Second, unmediated market dynamics are regarded as generating price instability in relation to markets of certain kinds. Third, uneven dynamics of accumulation within capitalism are regarded as fuelling inequalities of social power and distributive outcomes, and contributing in some cases to wider dynamics of instability.

To these material features of capitalism (understood as a distinctive institutional system of production, exchange and accumulation) may be added a fourth, cultural or normative dimension. For instance, in Polanyi's account of a 'market society', informal social norms that may otherwise have acted to mediate or counter unequalising or exploitative relationships and dynamics are regarded as being eroded through the diffusion of values that legitimise self-regarding and exploitative forms of social interaction (Polanyi 1944). On this view, distinctively capitalist norms and identities may themselves contribute to intensifying (as well as reproducing) the unequalising tendencies of the materialist structures of a capitalist market economy.

While capitalism may make important contributions to the realisation of social justice norms via its generation of economic growth, the unequalising tendencies that are produced through the process of capitalist processes of accumulation and wealth 
generation have - throughout the history of capitalism - given rise to the demand for a range of regulatory and redistributive interventions to constrain and compensate for the more negative consequences of the system (O'Riain 2000). Such embedding of the capitalist market economy in both formal and informal regulatory norms is claimed to contribute both to stability and legitimacy within the capitalist system - both enhancing its efficiency and countering its more exploitative and commodifying tendencies.

Within a capitalist political economy, such norm-based embedding of market economic relations can take place via a range of concrete institutional regimes, not all of which are directly relevant to this book's central focus on labour, production and trading systems within contemporary capitalism. ${ }^{7}$ Of most direct relevance are the systems of institutions governing the transnational business systems through which the relations of production and trade on which this book focuses are organised. Policy regimes relating to corporate and labour regulation are of particular relevance, as well as overarching governance regimes in the domains of international trade and investment.

During different phases of its development, and within different national and sub-national contexts, capitalism has been sustained and contained by formal and informal modes of regulation of varying kinds. The institution that has historically been charged with embedding capitalism has been the state. However the state has been floundering in its role as promoter of social justice norms during recent years.

\footnotetext{
${ }^{7}$ In particular, the focus of many writers on macroeconomic regimes and financial regimes as means of social embedding of capitalism is beyond the scope of most of this book's focus (for example (Ruggie 1982a, 2008; Wade 2008)).
} 
The period from the end of World War II to the present is often divided into two major periods: first, a period of "embedded liberalism" in the decades following World War II, during which time obligatory limits to commodification and unbridled accumulation existed in most capitalist economies. Second, observers point to a period of “neoliberalism”, regarded as extending roughly from the early 1970s to the present - or at least until its stride was interrupted by the still unfolding 'global financial crisis’ of 2008/2009 (see (Krippner et al. 2004; Ruggie 1982b; Wade 2008). ${ }^{8}$ In the discussion below, we first review the post-War period of 'embedded liberalism', and then review some of the new dynamics of 'disembedding' emerging during the 'neoliberal' phase of capitalist globalisation, and up to the present.

The embedding of capitalism by the state in the post-War period

During the post-War period, the state was the major underwriter of capitalist productive and social relations. Both international law and broader understandings of appropriate political practice reflected and reproduced the assumption that constraining the negative aspects of capitalism was properly dealt with almost exclusively within the national legal and political jurisdictions where impacts on specific populations occur, via the actions of the regulatory, welfare and/or developmental state. The presumption that such forms of governance should take place at the national level reflected both an idea that this was the level at which influence could be exerted on predominantly nationally oriented economies, as well as an assumption that nationally oriented political communities were the appropriate

\footnotetext{
${ }^{8}$ Some accounts, including many rooted in the French regulation school of political economy, add to this distinction a related one between "Fordism” and “post-Fordism” (Harvey 2006).
} 
level at which social justice norms should be defined and defended (Gereffi and Mayer 2004).

In the economic North the state in the post-War period was conceived as being responsible for 'social integration' - to be achieved by way of the protection and stabilization of social relations against unpredictability of fluctuating relative prices and 'system integration' providing for stable cooperation between capital and labour at the point of production (Streeck 2009). In other words, capital operated within a nationally embedded system of protection as well as restriction.

Detailed descriptions of the specific manner in which capitalism was embedded in social norms in the post-War era of the Keynesian welfare state have been undertaken elsewhere with far more depth than we could aspire to here, and it is not our purpose to rehearse these accounts (see (Jessop 2001a; Ruggie 1982b)). Instead, we focus on briefly reviewing some of the features of the post war governance regime of most direct relevance to the governance of those production, labour and trading relations in which we are centrally interested.

In presenting this account, sensitivity is required to the extensive variation across contexts and over time in the extent and means through which capitalism has been facilitated and constrained by regulation of differing kinds. Throughout this period, boundaries between market and non-market transactions have been continually contested, and pressure for the rationalisation of social regulation has been successfully exerted to different extents in different countries. ${ }^{9}$ In some cases the state

\footnotetext{
${ }^{9}$ As Streeck contends, 'the pursuit of economic advantage typically takes place, and is bound to take place, in the form of improvised circumvention or experimental re-utilization of institutions and
} 
acts to form alliances with 'capital' to reinforce and profit from unequalising dynamics of capitalism; in other cases it acts to counter such forms of power and promote protections of defined rights and standards of equality (Crouch and Streeck 2006). Such dynamics generate a great deal of space for variations in socio-political arrangements between different 'varieties of capitalism'. Significant differences also existed throughout this period between 'advanced' and 'developing' economies and states.

In advanced economies, various forms of social control over companies have been exercised since the rise of the company in its modern form, reflecting long standing and evolving debates about appropriate forms and levels of regulatory control. In the period immediately after the Second World War most developed country states took on a stronger role in mediating collective bargaining relationships between labour and capital. Networks of policies and regulations that came to constitute the modern welfare state were typically underpinned by organised labour, cooperatives, credit unions and other social institutions and movements seeking to subordinate the demands of the market economy to broader social purposes (Polanyi 1944). During the 1960 s and 70 s issues related to consumer and environmental protection and human rights became more prominent, as did concerns about the power and impact of transnational corporations in developing countries, strengthening social alliances in favour of social regulation in some areas (Jenkins et al. 2002).

In many developing countries, this period was a very mixed one from the perspective of social regulatory agendas. The role of the state vis a vis labour and 
capital varied significantly between national contexts at this time (Crouch 2005a, b). For many developing countries the post-War period was one in which states engaged in severe repression of labour, often on the rationale that this was necessary to national development to proceed (Deyo 1989). The latter part of the post-war period of 'embedded liberalism' was also one in which movements to control transnational corporations were particularly strong. In the late 1960s and 1970s at least 22 developing countries passed legislation of varying kinds controlling TNC activities (Jenkins et al. 2002).

The record was also mixed from the perspective of developing country farmers. A range of price setting mechanisms to control commodity prices played an important role in seeking to subordinate the market economy to social goals during this period. A range of international commodity agreements acted to smooth commodity price fluctuations via quota systems, while commodity boards of varying kinds operated at the national level in some countries to stabilise price fluctuations, in turn having a buffering effect on employment in some cases. On the downside, welfare regimes of the kind familiar to industrialised countries were developed in only very minimal ways in most developing economies.

Although the task of regulating capitalist market economies was undertaken primarily by individual nation states, regulation at the international level was not completely absent during this period. During the 1970s in particular there were intense debates at the international level - particularly within various UN fora - on the need to regulate corporations, and other aspects of the globalising capitalist economy. A number of international efforts to establish codes of conduct for the 
activities of TNCs emerged in the 1970s. ${ }^{10}$ However, while these were international in scope, they were seen primarily as supporting the efforts of developing country governments to regulate TNCs at the national level (Jenkins 2005). Despite a scattering of regulatory arrangements at the international level, the most important social regulatory regimes within the governmental domain therefore remained nationally bounded throughout most of this period.

The state has always been an uncertain underwriter of capitalist relations of production, and of course global production and trading systems have never been fully embedded in 'social justice norms' of the kind we define below. However, regardless of the great variation both between developed states and between developed and developing states, the spirit of the post-War period was very much dominated by a confidence in the central role of state led intervention in pursuit of social justice and development goals - however defined and implemented in different contexts at different times.

Globalisation of capitalist market economies and evolving dynamics of disembedding The dynamics of interaction between capitalist production and trading systems and state-centred institutions of public governance have evolved significantly in the course of the most recent wave of capitalist globalisation, roughly encompassing the

\footnotetext{
${ }^{10}$ The most comprehensive of these was the UN Draft Code of Conduct on TNCs which was developed by the UN Centre on Transnational Corporations set up in 1974. Several specialised UN agencies also developed codes covering particular aspects of TNC behaviour. These included the ILO Tripartite Declaration of Principles concerning Multinational Enterprises and Social Policy and the United Nations Conference on Trade and Development's proposed codes on Restrictive Business Practices and on the Transfer of Technology (Haufler 2001; Jenkins et al. 2002).
} 
last three decades. In today’s 'partially globalised’ economy (Keohane 2002) markets and market actors transcend national boundaries, international trade is increasingly organised through inter-firm networks and global supply chains, and capital flows freely around the world.

Many observers now suggest that contemporary economic globalisation has outstripped the capacity of national-level governmental and societal institutions to regulate markets and to compensate for undesirable effects of market transactions - to an increasing extent since the early 1970s. The post-War Keynesian welfare national state that developed in most advanced capitalist societies is now seen to be in crisis, as a result of mounting tensions generated by technological change, globalization, a range of economic and political crises and a shifting ideological landscape (Jessop 2002).

Such trends are widely claimed to be leading to regulatory and governance deficits, forming part of a wider process of contemporary 'disembedding' of globalising capitalist markets from social justice oriented norms. Weakness of state regulatory capacity is seen as resulting from three distinct trends.

First, state regulation has been undermined by an emerging disconnect between transnational power and national political governance. This increasing disconnect has been driven in large part by the extension of the scope of organisation of production beyond the boundaries of the nation-state. The transformation of many labour intensive industries in recent decades towards increasingly globalised production systems has been widely analysed (Gereffi and Memedovic 2003; 2005; McCormick and Schmitz 2002; Ross 1997). Beginning in the 1970s and accelerating through the 1980s and 1990s, production of apparel and textiles, toys, footwear, home electronics and other consumer goods destined primarily for consumer markets in the 
industrialised world has spread throughout the world, with manufacturing tending to cluster in a range of developing countries (Appelbaum 2006 (draft)). ${ }^{11}$ Such changes have been facilitated by the design of macro level policy regimes and institutions in which global production and trading relations (and associated investment regimes) are constituted, as well as by factors such as technological change, falling transport and communication costs, and rising economies of scale in certain sectors, all of which have also raised the incentives and lowered the costs of global systems of production and trade.

These changes have not been without benefits for newly industrialising countries. Participation in export-oriented production of labour intensive products has been one of the key ways in which a large number of developing countries have been able to attain comparative advantage in manufacturing, and thereby to access the opportunities such trade presents for export earnings and employment. However, such changes have also been associated with significant increases in the social power of a range of local and transnational private actors, which increasingly operate beyond the control of national governments and their populations. Such power often has significant consequences for the extent to which recognised social rights of workers and populations in the production process are protected and promoted. In particular, concerns have been voiced by many regarding the labour and environmental practices associated with the growth of global value chains in developing countries (Gereffi et al. 2005).

\footnotetext{
${ }^{11}$ Around $70 \%$ of global clothing exports now come from developing countries (Hale and Wills 2005, p.17).
} 
Earlier literature analysing dynamics of power within global production systems focused on the power of northern retailers and brands within 'buyer-led' global supply chains, ${ }^{12}$ who exercise significant influence over the terms of exchange with lower-tier suppliers (Gereffi et al. 2005) (Dicken 2000). However, some more recent analyses have highlighted the rising influence of large transnational contractors, based primarily in Hong Kong, Taiwan, South Korea and China, who operate factories around the world (Appelbaum 2006 (draft)). In part, this has resulted from (internal and external) economies of scale, as production in many sectors has more often than not become organized in regional clusters. This trend has also been associated with increasing consumption in Asia. Apo Leong, Ka-wai and Tucker (Chapter 15 of this collection) estimate that companies from Hong Kong and Taiwan are now the world's largest organizers or sellers of production, obtaining contracts from Europe, the US and elsewhere in the global North, and manufacturing products in developing countries. As the contribution by Andrea Maksimovic (Chapter 13) demonstrates, however, this changing dynamic is not merely the result of 'economic' factors; political dynamics have also come into play. In some cases Southern states have become increasingly confident in promoting their economic interests in multilateral forums.

\footnotetext{
${ }^{12}$ While retailers and brands are distinct, the line between these two categories of actors has become increasing blurred in many cases, as retailers such as Gap and Walmart have moved into manufacturing, creating their own private labels and manufacturing their own clothing lines, while some of the biggest brands (such as Nike, Guess and Liz Claiborne) have also moved into retailing (Armbruster-Sandoval 2005). As a result, we frequently use these terms somewhat interchangeably.
} 
Appelbaum suggests that the emergence of these large transnational contractors portends a dramatic shift of organisational power within global supply chains, as large factories provide a potential counterweight to the growing power of retailers. Not only does Appelbaum suggest that such trends may impact the relative power of contractors vis a vis retailers, he also suggests it may have implications for labour, both in terms of working conditions and prospects for unionization. He suggests that the increasing concentration of investment within 'giant factory complexes' (supply chain cities) has important implications for labour struggles since such concentrated capital may prove to be both more conducive and more vulnerable to labour militancy than small, dispersed production sites.

Second, state capacity has been weakened by the increasing complexity and informality associated with post-fordist processes of capitalist development (Harvey 1990). Such increasing complexity and informality operate to make regulation increasingly difficult in large part because the organisation of production has simply become more complicated (Collins 1990). In many economies, the range and complexity of work relationships has significantly expanded. There has been a broad trend amongst firms in industrialised countries towards vertical disintegration: that is, the breaking up of large, multi-function corporations into smaller units. The outsourcing of production, or vertical disintegration, has occurred in a significant number of industries, as producers recognise that they cannot themselves maintain cutting-edge technology in every field required for the success of their product (Gilson et al. 2009). This trend has also frequently been a consequence of privatisation, or part of the survival strategy employed by companies in previously sheltered industries as they have been exposed to international competition (Fenwick et al. 2008). Businesses have sought the benefits of lowering overheads and cheaper 
labour by passing risks and costs onto others in the supply chain. Workers have been drawn upon from unorganised or informal sectors of the labour force as well as from newly industrialised and developing economies.

The broad trend towards vertical disintegration has resulted in: (a) a proliferation of corporate forms and relations; and (b) a proliferation of people who would previously have been employed inside a firm being engaged in alternative ways, including as dependent contractors, independent contractors, employees or contractors of labour hire agencies, or as part of their own businesses (Marshall 2006). Labour relations have become far more convoluted as the structure of labour markets has changed both within industrialised and developing economies. These changes have created problems for labour law, which has increasing difficulty in defining an 'employer' and an 'employee'; yet these remain the parties between whom the bilateral employment relationship is assumed to have taken place (ILO 2005). ${ }^{13}$ As a consequence, increasing numbers of workers in both developing and developed contexts now work outside the reach of labour regulation and the social protections and welfare benefits which are most often attached to this legal relationship.

Third, such dynamics of disembedding have been further compounded by the influence of 'neoliberal' agendas, which have further driven a shift away from state

\footnotetext{
${ }^{13}$ The ‘traditional employer-employee’ relationship may only have dominated labour markets numerically in industrialized countries for a short time in historical terms, in the post war period to early 1980s. In developing countries, these kinds of working relations never attained such dominance. Regardless of the fact that vertically integrated businesses and their corollary in the labour market - the 'employee' - may be historical anomalies, the model forms the basis of labour regulation in most countries around the world.
} 
intervention oriented towards the promotion and protection of social justice norms in both developed and developing countries (Jenkins 2005; O'Riain 2000). Such agendas have underpinned the dismantling of a range of regulatory systems of the kinds outlined above. Liberal policy regimes focused on facilitating global competitiveness and coordination and delegating certain regulatory responsibilities to private actors via a broad range of instruments: labour market deregulation; decreased real wages and work-related social benefits; the privatization of public services; and new bodies of law protecting TNCs and foreign investors. In some cases, legal protections for working conditions and minimum wages were weakened.

In many countries, forceful opposition to binding industry regulation emerged in the 1980s, led by organised business interests, undermining the embryonic developments that had been made in some countries and at the international level during the preceding decade (Richter 2001, p.8). More broadly, a policy climate emerged which was distrustful and even openly hostile towards the state, of 'command and control' regulation, of 'planning' and 'protectionism', and of traditional forms of trade union organization (Ruggie 1982a; Ruggie 2003).

This was also a time during which international commodity agreements were largely dismantled, as were marketing boards and other agencies that had previously been involved in the stabilisation of commodity prices. This disbanding of collective institutions designed to facilitate price coordination was often accompanied by broader processes of both price liberalization and trade liberalisation. Since their introduction, such regimes have been associated with declining social and labour protections as well as instability and fluctuations in global commodity prices.

Again, important differences between countries can be observed in relation to the extent and nature of emerging regulatory deficits. The reach of globalising 
dynamics as well as the impact of neoliberal policy regimes on various forms of social regulation and redistribution have varied very substantially, as mediated through a broad range of institutional, political, social and sector specific factors particular to local contexts (Hall 2007). Nevertheless, across a very wide range of contexts, contemporary processes of liberal economic globalisation have had important implications for the capacity of social regulatory systems at the national level to control and/or compensate for any negative effects of market capitalist institutions.

It may be that we are currently witnessing a shift in terms of the willingness of the state to underwrite capitalist relations, as a consequence of the financial crisis of 2007-9. Thus far there are no indications that this entails a renewed readiness to regulate relations between capital and labour. However, there is a growing emphasis upon providing price stability. It remains to be seen how these new dynamics will play out in relation to the central concerns of this book.

\section{Searching for solutions: emergence and evolution of new governance initiatives}

In response to the kinds of perceived deficits described above, a plethora of (frequently overlapping and competing) governance mechanisms with similar aims have emerged, often seeking to govern the same subjects. Some are market- and non-

state-based, whilst others are associated with multilateral or unilateral state-based international regulatory mechanisms. These initiatives are heralded by many as potential solutions to such governance deficits, in light of their performance of a range of developmental and regulatory functions that extend beyond traditional legal or statutory forms of governance.

As outlined above, one of the major analytic tasks of the book is to make sense of the emerging initiatives around agendas of fair trade and corporate accountability 
as progressive movements towards the development of increasingly transnational regimes of social governance. In other words, we seek to understand to what extent claims about the 'second double movement' (Gereffi and Mayer 2004; Polanyi 1944; Ruggie 2008) towards the 're-embedding' of a liberal market economy (this time at a transnational or global level) are given support by the emergence of this range of social regulatory initiatives.

\section{Different types of governance initiatives}

In this section we examine initiatives of several kinds, the origins and key features of each of which are introduced in the following discussion. First, we briefly review the three clusters of initiatives (and their more collaborative and transformative variants), based around fair trade, CSR and campaign driven initiatives. This introduction aims to assist readers unfamiliar with these agendas to more easily navigate the sections of the book containing cases of each kind. Following this examination of different kinds of non state initiatives, we then briefly contrast two approaches to conceptualising the role of the state in seeking to engage with and support non-state governance initiatives of this kind; these can likewise be characterised as collaborative versus confrontational in orientation.

\section{Emergence and development of fair trade}

Part I of this book deals with fair trade initiatives. The term fair trade is used extensively to refer to trading principles from a diverse range of ideological perspectives - from free traders, to protectionists to those seeking to promote forms of globalisation based on principles of social justice and poverty reduction. In this book the term generally refers to the range of movements, campaigns and initiatives in this latter category, mobilising consumers and social activists in the global north to 
promote principles of global trade that support marginalised producers and workers in developing countries.

The fair trade movement is typically defined in this sense as referring to a set of groups formally linked through participation in the FINE network, comprising the Fairtrade Labelling Organisations International (FLO), the International Federation of Alternative Trade (IFAT), the Network of European Worldshops (NEWS) and the European Fair Trade Association (EFTA). In the US the Fair Trade Federation falls under this umbrella also (Raynolds et al. 2007b). These organisations seek to use north-south trade as a means of empowerment rather than one of exploitation, and thus to improve the livelihoods and wellbeing of producers via support for organisational strengthening, providing a better price and a social premium, offering stable trading relations based on principles of partnership, and promoting broader systemic change via awareness raising among consumers and broader campaigning efforts for changes in the rules and norms underpinning the liberal international trading regime. The widely cited definition of fair trade as agreed by the umbrella organization FINE is:

"Fair trade is a trading partnership, based on dialogue, transparency and respect, that seeks greater equity in international trade. It contributes to sustainable development by offering better trading conditions to, and securing the rights of, marginalized producers and workers - especially in the South". 14

Understood in this sense, fair trade has emerged as an 'alternative' normative and institutional system to organise and govern production and trade in a range of sectors.

\footnotetext{
${ }^{14}$ See: http://www.eftafairtrade.org. See also (Murray et al. 2003; Raynolds 2002a, b; Raynolds et al. 2004)
} 
The specific norms of 'fairness' that the fair trade system seeks to entrench within this alternative institutional system have several dimensions. Much marketing of fair trade products - particularly within the FLO system - tends to focus on the principle of a 'fair price' for producers, incorporating both minimum prices (specified in relation to each particular product line), and an additional 'social premium'.15 Moreover, the system attempts to entrench principles of democratic decision-making and social and environmental sustainability across all stages of the supply chain. Participating producers must be organised within co-operatives or other organisations with democratic, participatory structures, and must comply with a range of economic, social and environmental standards. Buyers must comply with FLO’s trade standards: as well as payment of a minimum price and a social premium, these require provision of pre-financing if requested by the producer group, and a commitment to long-term trading relationships. ${ }^{16}$

The system as a whole retains a dual character, as both an alternative trading system, and as a social movement (Jaffee 2007; Smith and Barrientos 2005). The institutional core of the system is built around its trading activities, which create ‘alternative’ supply chain systems linking producer co-operatives to not-for-profit ATOs based in consumer countries. These alternative supply chains therefore operate

\footnotetext{
${ }^{15}$ FLO certification claims to guarantee "that every product was produced by a fair trade certified organization which was paid the fair trade price”.

${ }^{16}$ Details of FLO standards are available at: http://www.fairtrade.net/generic_standards.html. IFAT, which coordinates a broad range of fair trade organisations beyond the FLO system, lists nine core categories of fair trade standards: creating opportunities for economically disadvantaged producers; transparency and accountability; capacity building; promoting fair trade; payment of a fair price; gender equity; working conditions; child labour and the environment.
} 
via a relatively durable institutional structure in which production, exchange and governance activities are all coordinated by the same sets of actors: producer cooperatives and ATOs. This core institutional structure has loose links with a broad collection of organizations and networks that have wider 'social movement' characteristics (Tarrow 1994).

Although the fair trade movement shares a broad range of core principles in common, there is a great deal of diversity within the movement, in terms of both goals and institutional structures. Indeed, in recent years in particular, significant forms of conflict have emerged within the system between those with divergent visions of how best to strategically position themselves in relation to the collaboration/confrontation divide. Such dilemmas centre around what (Jaffee 2007, p.1) has referred to as a fundamental paradox at the heart of fair trade:

"In its efforts to achieve social justice and alter the unjust terms of trade that hurt small farmers worldwide, fair trade utilizes the mechanisms of the very markets that have generated those injustices".

Such tensions have often played out in relation to the divergent orientations of the certification system within fair trade organised around the Fairtrade Labelling Organisation (FLO), the less formalised system organised more loosely around what now goes by the name of the World Fair Trade Organisation (IFAT), and a range of other networks or associations of fair trade organisations such as the Network of European Worldshops and the European Fair Trade Association. Many talk of the FLO system as reflecting a more ‘mainstream' or collaborative approach, while IFAT along with the other looser networks are seen as reflecting a more 'alternative', 
transformational vision. ${ }^{17}$ Of course there is significant diversity within and between each in relation to different aspects of this divide, but this rough distinction plays some useful role nevertheless.

The tensions between alternative and more mainstream approaches may have been present throughout the history of Fair Trade (Raynolds et al. 2007a); however, they have intensified in the context of the movement's rapid growth into new commodities, production regions and market niches. Attempts to scale up fair trade volumes have led to expanding business partnerships involving large traders, distributors, supermarkets and other mainstream retailers. This has raised questions about whether such changes are likely to erode the movement's mission of challenging the terms of liberal international trade. Such forms of evolution and expansion within the fair trade movement also present challenges for fair trade's internal governance. The desire to remain or become more responsive to Southern producers' local development agendas is in some senses in tension with the desire of some within FLO to tighten regulatory procedures in line with ISO standards, or to reform the Fairtrade business model in line with market and commercial demands. These competing pressures strain the democratic and transformative institutional capacities of the governance systems that oversee fair trade.

\section{Emergence and development of agendas of CSR}

As in the case of fair trade, the range of movements and initiatives encompassed under the broad umbrella of 'corporate social responsibility' initiatives share certain

\footnotetext{
${ }^{17}$ See for example Hutchens in this volume in relation to the distinction between FLO and IFAT; see also (Low and Davenport 2005).
} 
features and logics in common, but also diverge widely; this cluster of initiatives can also be roughly categorised in relation to a collaboration/confrontation divide.

The chapters in Part II of this book all deal broadly with these kinds of initiatives. While there is no commonly agreed definition of CSR, there are a number of core goals and techniques we can point to as commonly shared characteristics. Broadly, corporate responsibility refers to practices that recognise corporations as bearing some responsibilities to minimize socially or environmentally harmful practices, and to strengthen controls on human rights, social, environmental and governance related activities (Blowfield 2005; Carroll 1999; Zerk 2006). An embrace of principles of corporate social responsibility therefore involves an acknowledgement that social objectives must in some cases be given priority by corporate managers alongside profit oriented objectives, ${ }^{18}$ whether or not these are viewed as being complementary or in conflict - a point on which there remains much disagreement.

Many definitions focus on CSR as a voluntarist agenda, encompassing only that which goes beyond legal compliance. This view is reflected in the definitions offered by key government actors such as the UK government and European Commission, as well as many business groups (McBarnet et al. 2007; Zerk 2006). Others adopt a broader definition, seeing CSR as a particular normative view of the obligations of businesses in society, which may be governed via legal as well as voluntary instruments. Such obligations are defined for example by Zerk (Zerk 2006) as encompassing the responsibility of business to operate ethically and in accordance

\footnotetext{
${ }^{18}$ These may include considerations such as boosting sales, protecting brand, attracting and retaining talent, promoting employee productivity, reducing production costs, attracting investment.
} 
with relevant legal obligations, and to strive to minimise any adverse effects of its operations and activities on the environment, individual health and wellbeing and broader social goals. This broader definition is the one adopted for the purposes of this book, in recognition of the complex ways in which government, business and civil society interact in shaping the social, economic and legal pressures that underpin contemporary CSR movements (Fox 2004; McBarnet et al. 2007).

Specific corporate practices associated with CSR agendas may include compliance with the law and broader professional or moral codes; philanthropic or charitable work; promotion of agendas of accountability and stakeholder engagement; or broader protection or promotion of social, environmental and human rights standards built into the way the core business operations of a company are managed. In some cases broader agendas such as fairness to suppliers and customers, opposition to bribery and corruption or issues such as responsible marketing and lobbying or internal promotion of workplace diversity can also be part of the CSR agenda (McBarnet 2007). More formal CSR practices may include codes of conduct and other sets of principles and guidelines, social and environmental management systems, Occupational Health and Safety and company-community relations, triple bottom line accounting and company sustainability reporting, internal and external monitoring and verification, stakeholder dialogues (these are surveyed in more detail by Utting in this volume). CSR continues to address domestic corporate policies such as community relations, environmental practices and diversity but its primary focus is now the conduct of global corporations, especially in developing countries. In particular, corporate responsibility for labour and human rights practices of supply chain partners has become a central dimension of contemporary CSR (Vogel 2005). 
Variation is also significant within each of these clusters of CSR activity. Corporate codes of conduct for example vary widely in their scope, in the range of standards they encompass, and in the degree of transparency and worker participation associated with processes of code design, implementation, monitoring and verification (Jenkins et al. 2002). There is also some variation in the scope of the responsibilities they encompass - whether they regard responsibilities of northern businesses and consumers simply to workplace issues related directly to the process of production of goods and services, or whether they encompass broader social and developmental responsibilities that would encompass "the production and reproduction of labour power in the global economy” (Jenkins et al. 2002, p.7). Overall, the picture is generally agreed to be one of extreme unevenness in the scope and substance of protections or benefits offered as a result of the CSR agenda (Fox 2004; Jenkins et al. 2002; Newell and Frynas 2007; Utting 2005).

Likewise, the motivations for businesses to embrace discourses and practices of corporate social responsibility - often beyond their legal obligations to do so - also vary: some are strategic, others defensive, and still others altruistic or public-spirited (Vogel 2005). This is relevant to our broader interest in exploring the tensions between relatively collaborative versus confrontational approaches, which have played out particularly importantly in relation to the question of voluntarism. On one extreme is the position of Milton Friedman, who famously declared that the only social responsibility of business is to increase its profits (Friedman 1970). On the other side are those who point to the ways in which certain privileged corporate powers are conferred in law and by society to facilitate the furtherance of public purposes, suggesting that these should operate together with legitimate private purposes to underpin a more expansive notion of corporate responsibility. Among 
those who acknowledge at least the possibility of some coherent notion of corporate social responsibility there is a further divide between those who seek to justify such responsibilities as part of a broader, enlightened corporate self interest - often referred to as the 'business case' for corporate social responsibility - and those who view such responsibilities as more expansive moral and legal responsibilities, at times in zero sum conflict with private purposes and concepts of value (Zerk 2006).

In concrete terms, such differing normative views have been given expression in models of corporate responsibility of divergent kinds. At one end of the spectrum are the clusters of wholly voluntary and business led initiatives such as individual company codes of conduct, which may include brand, retailer or in some cases factory based codes, or industry association codes such as Worldwide Responsible Apparel Production (WRAP) in the garment sector. These stand in contrast to collaborative multi-stakeholder initiatives such as the Ethical Trading Initiative or Fair Trade Association, which are still voluntary from a legal perspective, but which encompass more extensive input from non-profit and stakeholder groups of various kinds. These may build in broader mechanisms for enabling stakeholder participation (if not control), though they also tend to share similar limitations in scope. Further along the spectrum again are those initiatives that seek to build legal frameworks for corporate responsibility. In the UK for example, a key player in shaping recent debates about the appropriate role of law in underpinning norms of corporate social responsibility has been an alliance of UK NGOs, the CORE (Corporate Responsibility) Coalition. Agendas of this kind that seek to find new ways for states to reinsert themselves into regulatory processes are discussed further below. 
Emergence and development of activist campaigns as part of a corporate accountability movement

Activist campaigns have played a central role in advancing agendas of both fair trade and corporate responsibility. They have underpinned and in many cases propelled the development of CSR movements; they continue to play an important role in monitoring and holding accountable voluntary CSR initiatives; and in many cases they have played a growing role in pressing for stronger forms of state regulation of CSR principles and programs. The chapters in Part III of this book generally concern worker-based activist campaigns and associated grassroots organising activities.

Such campaign-oriented approaches have emerged together with the development of social movements organised around the assertion of new principles of binding, non-discretionary corporate responsibility. Often these have been based around concerns about corporate impact on human rights and the environment, though commonly these have been directed towards asserting more expansive obligations of social or global justice. Such claims have often been linked to empirical claims about liberal, market and corporate led globalisation - in particular, claims that such globalising processes have been associated with a secular rise in corporate power, and with the intensification of corrosive social impacts of corporate activity (Korten 1995; Starr 2000).

Such movements emerged particularly strongly during the 1990s, building on increasing organisation within prominent consumer sectors such as garments and coffee, in which networks of human rights and labour activists attempted to improve working conditions and raise wages for workers in developing countries via a series of public campaigns targeting both companies and consumers in industrialised countries - particularly North America and Europe. The emergence of such 
campaigns can be understood as being in part a response to globalisation of systems of production and trade, and the increasing perception that corporate decision makers who were accumulating increased power should be held directly accountable for the impacts of such power on affected individuals and communities (Macdonald 2007). The emergence of such campaigns has also been underpinned by the increasing capacity of activists in the global north to communicate directly with workers in distant factories, together with broader changes in the focus of the NGO sector in the US within the post-Cold War political context. As the agenda emerged, and was developed through the success of campaigns focused on prominent brands such as Nike, ${ }^{19}$ an even broader range of social and political organizations became mobilized around the issue. $^{20}$

Initiatives of this kind tend to be more confrontational in orientation, rejecting the proposition that CSR agendas can plausibly be advanced on the basis of a 'business case' alone, and seeking to generate broader forms of social influence and control over corporate activity to bring it into line with the social justice and human rights norms that such movements consider businesses have an obligation to conform to. For many, mandatory legal requirements are regarded as a distinctive and in some

\footnotetext{
${ }^{19}$ One particularly influential campaign was the anti-Nike campaign begun by Jeff Ballinger (contributor to this volume), former head of the AFL-CIO Jakarta office, who founded Press for Change in 1998. This drew wide media attention, leading other groups to initiate anti-Nike campaigns of their own, thereby drawing such broader groups into organizing efforts around the sweatshop agenda.

${ }^{20}$ These included a variety of organizations including NGOs, unions, immigrant workers, as well as a wide range of individuals and organizations coordinated through email lists, student groups and churches.
} 
contexts irreplaceable form of influence over corporate behaviour, though most also recognise the constructive role that can be played by other sources of influence such as corporate culture or consumer pressure.

Nevertheless, important areas of variation exist within this broad category of activist campaigns and corporate accountability movements. Some have been more consumer and northern brand focused, while others have been more participatory in their objectives and organisational structure. Given the frequently significant disparities between the specific priorities and capabilities of such a diverse range of non-state actors, a range of distinct campaign strategies were adopted; while some groups focused on targeting firms to reform supply-chain management practices, others engaged in research, public education or promotion of grassroots organizing among workers (Harrison and Scorse 2004; Macdonald 2007).

In recent years, many campaign based initiatives have started to identify explicitly with discourses and agendas of 'corporate accountability' as distinct from simply corporate responsibility. This shift has tended to be associated with rising interest among activists and legal scholars in the role of more confrontational strategies, which have at times entailed the mobilisation of legal mechanisms - often for purposes different from those for which they were intended - as weapons in struggles over power and values.

What role for the state? Collaborative engager or agent of corporate accountability Debates between 'soft/voluntarist' versus 'hard/legal' modes of regulation have important implications for the role of the state in interacting with emerging non-state governance mechanisms. The contributions in Part IV of this volume engage with such debates. As these chapters show, disputes over the appropriate role of 
governments and law-makers (courts, legislatures, government agencies and so on) in relation to agendas of corporate responsibility have taken place on a number of levels. Recurring through much writing on voluntary initiatives such as civic, corporate and worker based interventions has been a recognition that initiatives keep stumbling against obstacles of coordination and enforcement, in the absence of a strong and supportive role of the state. A key question that tends to emerge therefore is to what extent does the state need to be 'brought back in', albeit in potentially new ways?

Relevant academic literatures suggest that a number of new agendas are developing in relation to the role of the state in underwriting corporate responsibility and accountability. Early attempts to promote ethical corporate practices by states, reflecting the influence of New Governance or reflexive regulatory theories, involved increasing uses of cooperative, 'soft law' mechanisms by the state as a substitute for its traditional 'command and control' techniques of enforcement as means of encouraging higher labour and social standards. These kinds of legal strategies are seen as being based importantly on dialogue and collaboration, as government and business seek to engage in processes of mutual learning and increase compliance via preventative and cooperative efforts (Parker 2002). Non-state actors are seen as responsible and empowered participants through all stages of the regulatory process, rather than being the resistant subjects of oppositional forms of top down regulation. This view regards regulation as more likely to be effective if used in a manner that is responsive to and draws upon existing distributions of power and resources among economic and social actors (Howe (Chapter 18) and Lobel (Chapter 17) this volume; (Ayres and Braithwaite 1995)). Partly for this reason, such models have often tended to de-emphasise worker empowerment and traditional trade union strategies. 
According to this view, the challenge for government is to determine how best to try and facilitate the active involvement of private actors in public action. Businesses are offered opportunities to engage in organisational learning, and to design corporate responsibility methods that are appropriate to their own business cultures. The role of government changes from regulator and controller to facilitator and coordinator. Law becomes a process of shared problem solving rather than an ordering activity.

A range of initiatives at national, supra-national and international levels have enabled governments to engage with CSR initiatives via non-legal or quasi-legal approaches. Voluntary or soft law mechanisms at the international level include the National Contact Points for the Organisation for Economic Co-operation and Development's Guidelines for Multinational Enterprises ${ }^{21}$, the Compliance Advisor Ombudsman (CAO) of the World Bank Group ${ }^{22}$, and European Bank for Reconstruction and Development's Independent Recourse Mechanism (IRM) which assesses and reviews complaints about Bank-financed projects ${ }^{23}$. A range of other transnational initiatives have also had government involvement and support of varying kinds, including multi-stakeholder initiatives like the Ethical Trading

\footnotetext{
${ }^{21}$ See http://www.oecd.org/department/0,3355,en_2649_34889_1_1_1_1_1,00.html, accessed 8 May 2009.

${ }^{22}$ This is the independent recourse mechanism for the private sector arm of the World Bank Group: see http://www.cao-ombudsman.org/, accessed 8 May 2009.

${ }^{23}$ The IRM gives local groups that may be directly and adversely affected by a Bank project a means of raising complaints or grievances with the Bank, independently from banking operations: http://www.ebrd.com/index.htm, accessed 8 May 2009.
} 
Initiative. ${ }^{24}$ Governments in the EU, as well as US states such as California and Massachusetts, have also promoted CSR agendas by including CSR requirements in their own procurement contracts (McBarnet et al. 2007, p.43).

While these soft regulatory models have been highly influential across a range of fields, they have also attracted significant controversy. The field of labour regulation is typical in both the influence and the contestation of such approaches. Critics hold that central to the design of labour relations institutions is the idea that the parties have interests that are sometimes overlapping but often in conflict. Industrial relations institutions seek to remedy (if only partly) unequal bargaining power between the parties. On this basis, voluntary or 'soft law' mechanisms have been criticised for treating decent work deficits as a ‘technical problem’ (Murray 2001): reducing democratic political control and flattening power relations (in formal but not substantive terms) compared with traditional labour law mechanisms (Blackett 20012002).

While interest in soft law approaches does not seem to be waning, a greater focus within the literature more recently has been on forms of 'meta-regulation' that combine soft and hard regulatory techniques (McBarnet et al. 2007; Parker 2007). Such regulatory approaches use methods that encourage collaboration between public and private actors, but also employ more confrontational techniques such as penalties and the ability of wronged parties bring suits against wrong-doers in order to enforce compliance with desired standards. Lobel (Chapter 17 of this volume) provides examples of these types of mechanisms in the area of occupational health and safety in the US.

\footnotetext{
${ }^{24}$ See http://www.ethicaltrade.org/, accessed 8 May 2009.
} 
A further development surrounding questions about the role of the state in promoting corporate responsibility and accountability has been the employment of existing legal causes of action by civil society actors in inventive manners to enforce principles of responsible corporate practice. Unfair competition and false advertising legislation have been used as a basis for trying to hold companies accountable for claims made in their CSR marketing materials, such as in the Californian case Kasky v. Nike; 45 P 3d 243 (Cal, 2002)). A class action aiming to enforce codes of conduct also went before the Californian courts under California’s Unfair Business Practices laws; this action claimed that Walmart failed to meet their contractual duty and made false and misleading statements to the American public. ${ }^{25}$ The US Alien Tort Claims Act, 28 U.S.C. 1350 of 1789, which enables civil lawsuits to be brought in the US for extraterritorial actions "committed in violation of the law of nations or a treaty of the United States” has also been used on a number of occasions to enforce international corporate responsibility (Vogel 2005, p.168). Such claims are sometimes successful in gaining publicity and providing greater corporate transparency, partly through the ‘discovery’ processes by which claimants have been able to gain access to documents previously not available to the public. Nevertheless, the use of such private law mechanisms places great financial and time demands on claimants, and because of the nature of the causes of action, even where the claims are successful on their own

\footnotetext{
${ }^{25}$ On September 13, 2005, workers at Wal-Mart suppliers in China, Bangladesh, Indonesia, Swaziland, and Nicaragua filed a class action lawsuit in Los Angeles under California’s Unfair Business Practices Act, claiming Walmart failed to meet their contractual duty and made false and misleading statements to the American public. See www.laborrights.org
} 
terms, the changes required of company behaviour in legal terms remain restricted in scope.

In view of the limitations of the use of existing private law mechanisms as a basis for corporate accountability, and the governance failures discussed in earlier sections, there have been widespread calls from many promoting corporate accountability agendas to strengthen legislative and regulatory responses at national, regional and international levels. Such calls have two objectives. One is the reformation of state-based regulation so as to better fit with post-Fordist modes of production and accumulation. On the one hand, this entails grappling with nonstandard working arrangements and extending the reach of regulation outside the traditional workplace or factory, as well as providing new rights to consumers. On the other, it involves extending regulation outside national jurisdictions. The second objective, then, is to explore ways in which an international legal framework can promote stronger accountability for corporate behaviour. Efforts directed towards this goal include the ongoing field of work around John Ruggie's mandate as the UN Secretary General’s Special Representative on Business and Human Rights, which is seeking to clarify the responsibilities of business under international human rights law (Human Rights Council 2007, 2008). Such agendas and debates are, however, still ongoing, and legal provisions remain both significantly limited and widely contested.

\section{Evaluating emerging systems of governance}

Throughout this chapter so far, we have been making reference to the idea that the initiatives examined by this book reflect a common agenda of seeking to embed contemporary capitalism in a set of norms that identify with discourses of '(global) social justice’ of varying kinds. 
Activists and other social actors promoting governance initiatives of the kind in which this book is interested are often united by their shared invocation of discourses and rallying cries of 'globalising justice'. Discourses around the concept of 'global economic justice' have been particularly common, with slogans such as 'Make Trade Fair' and 'Globalise Justice' being widely used as symbols and signposts of resistance to liberal forms of globalisation. ${ }^{26}$

The term 'social justice' is however highly ambiguous and contested, and in the discussion that follows we attempt to provide a working definition of the term. This definition provides an important reference point for the evaluation presented throughout the book of the performance of these different initiatives.

\section{Norms of social justice around which these initiatives are oriented}

At its essence, the concept of social justice refers to the fairness or justice of distributions of rights, opportunities and/or resources within a given society (Cramme and Diamond 2009, p.3). Within this broad definition, there is much variety and contestation regarding the scope of burdens and benefits considered relevant to considerations of justice, and the principles of fairness or justice that should apply to the distribution of such goods. Such variation exists both across different theoretical accounts of justice and different political currents of social justice activism. ${ }^{27}$ Despite

\footnotetext{
${ }^{26}$ See for example: http://www.oxfam.org/en/campaigns/trade; http://www.tjm.org.uk/about.shtml; http://www.startribune.com/nation/43744977.html?elr=KArks:DCiUMEaPc:UiD3aPc:_Yyc:aUU

${ }^{27}$ Theoretical traditions and those associated with political and activist discourse do not map cleanly onto each other, with each borrowing in rather fluid, hybrid and often only implicit ways from one another.
} 
such diversity, several key ideas tend to recur within theories and discourses of social justice.

An emphasis on provision of basic rights or needs of some kind is central to most definitions of social justice. This may refer to human rights applying globally (Kuper 2005; Pogge 2002), or to broader accounts of social entitlements associated in particular with national citizenship (Marshall 1950; Miller 1997, 1999). While the scope of rights of all these kinds is contested, categories of rights related to freedom from poverty and basic protection for labour rights are widely recognised, and of particular relevance to this book. Such a rights oriented perspective tends to emphasise the need for social regulatory instruments to seek to alleviate poverty and increase the freedom of workers and communities to exercise meaningful control over the conditions in which they work and live.

Concern for equality also plays an important role in most accounts of social justice, variously referring to equality within national societies (eg between capital and labour or between different genders or ethnicities), or equality between the rich and poor in the developed and developing worlds (Cramme and Diamond 2009; Miller 1997). While there is much debate over the question of the 'equality of what?' is important from the perspective of justice, both equality of opportunity and equality in the distribution of broader kinds of social goods or capabilities are commonly identified (Miller 1991).

While theoretical and activist led accounts of social justice have therefore varied widely, a broad overlapping consensus can be roughly identified around these core concerns of protecting basic rights and mitigating inequality via the creation of just systems of social institutions; these concepts are at the centre of our working definition of social justice. 
Ambiguity is much greater in relation to the question of the appropriate scope of these principles of social justice; specifically, the question of what rights (and dimensions of equality) should be extended beyond national borders? In other words, in what sense can we talk meaningfully of something called 'global social justice', as we do in this book?

Within theoretical political and philosophical debates around the issues of social and global justice, analyses of social justice and global justice have tended to be rather sharply differentiated. Theoretical interest in global justice has gained ground only in the last one or two decades, following in particular the contributions of authors such as Charles Beitz and Thomas Pogge (Beitz 1983, 1999, 2001; Pogge 2001, 2002). Much debate has subsequently focused on the question of what constitutes the appropriate scope of justice - some take the national society or political community and its basic institutions as the subject of justice, while others seek to extend principles of justice to the global domain.

Within activist discourses, such debates have not been so clearly identified. In such contexts distinctions between social and global justice have often remained rather blurred, enabling significant ambiguity to remain regarding the extent to which norms of social justice are claimed to extend to the transnational level (though there is almost universal agreement among social justice activists on at least the global applicability of human rights norms).

Although there is little agreement among global justice activists regarding which social justice norms as conceptualised at the domestic level should be extended to the transnational domain, there is at least a general agreement that some such norms (and associated responsibilities) should be so extended. Moreover, activist claims about global distributive norms are almost unanimous in characterising such 
norms as having the special normative weight of justice claims, as opposed to simply claims for charitable forms of assistance (eg. (Bendell 2004, p.5)).

Our use of the term 'global social justice' throughout this book seeks to capture a sense of this prevailing ambiguity in relation to questions of scope, while also reflecting the convergence of views around the view that justice claims of some kinds do extend beyond the scope of the national political community. This term therefore aims to accommodate a broad range of positions regarding the scope of the social justice obligations that extend beyond the national level. ${ }^{28}$

What role do these justice norms play in our overall evaluation of new governance initiatives?

In order to develop a means of evaluating the performance of competing and interacting governance systems, we need some kind of organised basis for considering not only the global social justice norms they articulate, but also the specific ways in which they seek to bring about institutional transformation. This task is not straightforward, as we require a way of conceptualising a meaningful 'metric' of performance which somehow captures the ambiguities and hybridities described earlier in relation to what these initiatives are, and what they seek to do. When we ask in relation to these initiatives: 'what works', we need to be clear on precisely what

\footnotetext{
${ }^{28}$ In using this term we recognize that different principles may well be held to apply in relation to social relationships of different kinds, and do not seek to assert that the difference between social and global justice is merely a question of scope - a meaning that Miller (in (Cramme and Diamond 2009, p.23) associates with the popular phrase 'global social justice'. Rather, we intend the term to capture persistent ambiguity on this and other basic definitional questions.
} 
they aspire to achieve, so our performance metric can encompass a suitably multidimensional set of criteria.

We suggest that in simple terms we can conceptualise these initiatives as adding value to the broad project of promoting a more just global economic order at three levels:

- First, they seek to contribute to more just outcomes for individuals and communities via contributing directly to the protection and promotion of human and social rights and welfare.

- Second, they contribute to justice as a function of the institutional design features they embody; to the extent they operate as power-wielding governance mechanisms in their own right, we can seek to roughly evaluate the fairness of the institutions they embody (as structural channels for the distribution of benefits and burdens).

- Third, they contribute to the ultimate goal of a more just global economic order via the processes of change they promote and facilitate within the broader governance system in which transnational economic relations are embedded, contributing in this sense as vehicles of broader institutional change.

In some respects then, qualities of institutional structures and processes may be regarded as valued outcomes in their own right. In other respects, changes to institutional structures and processes are valued largely as means to other ends. As we explore the central questions of this book, we therefore seek to track and critically examine the contributions and shortfalls of these initiatives at each of these levels (if only at the schematic and exploratory level of evaluation rendered possible in view of the eclectic nature of contributions discussed above). 
In order to carry these criteria through as a basis for evaluation of the impacts of the initiatives on 'globalising justice' - that is, their contribution to embedding transnational economic relations in global justice norms - we need to elaborate further what contributions of these kinds would look like in concrete form. While analysis of documented outcomes is reasonably straightforward, the challenge of how to operationalise the institutional criteria (the second and third dimensions of change identified above) requires more elaboration. The task is complicated by the fact that specific institutional qualities that contribute to promoting justice via each of the two institutional channels identified above are often entangled and overlapping in practice. We attempt to deal with this difficulty by identifying four major clusters of institutional characteristics that we suggest contribute in varying ways to advancing the two institutional channels for the promotion of global justice norms identified above. These characteristics can be roughly categorised as:

A) Institutional capacities to directly promote and protect worker and producer wellbeing;

B) Opportunities for worker and producer influence over business decision making;

C) Capacity of institutions to promote trust and cooperation; and

D) Definitions of business, consumer and state rights and responsibilities - as embodied in and promoted by institutional arrangements - that are supportive of social justice norms.

Category A refers to the functional qualities of institutions, encompassing those technical capacities that enable particular institutional arrangements to contribute directly to protecting social justice outcomes for individuals and communities. Such capacities may include those oriented towards enhanced economic production as well 
as those that enhance the ability of institutions to perform regulatory or redistributive functions. Strengthening capacities of these kinds are often a major goal of 'capacity building' dimensions of governance initiatives. This category gives rise to two distinct criteria of institutional transformation that can be identified as supportive of social justice norms:

- Strengthening technical capabilities of governance institutions and key players within them

- Contribution to underlying productive capabilities of the economic system being regulated

Category B describes levels of participation or influence for workers and producers over decision-making regarding labour issues in businesses. These categories reflect themes commonly analysed within industrial democracy literature (Blumberg 1968; Coates 2003) and democratic literatures more broadly (Pateman 1970). In this literature, the right to information is an important constitutive element of deeper participation in decision-making: it is impossible to influence decisions without having information about the decision at hand. However, information in itself does not represent control. Likewise, consultation by employers with labour or producer representatives in relation to labour issues is an important step for participation but does not result in control over decision-making. Employers and managers can consult with employees or producers and subsequently ignore their expressed preferences. Stronger forms of participation in decision making include codetermination, entailing the right to veto (right to reject) decisions proposed by management and propose new ones. It is important to distinguish, also, between direct participation by workers and producers and indirect participation via workers' or producers' representatives. Direct involvement can result in a greater increase in 
individual agency, but only where it does not undermine aggregate or collective influence over business decision-making. Based on these considerations, we have developed the following criteria as indicators of the extent to which processes of institutional change are supportive of social justice norms:

- Increased right of consultation for worker/producer organisations regarding business decisions

- Increased right of veto for worker/producer organisations over business decisions

- Direct opportunities for affected individuals to exercise choice/agency over business decisions

As we have seen in this introductory chapter, building of trust and cooperation is seen by some to be one of the crucial benefits of governance initiatives (reflected in category $\mathbf{C}$ ). Initiatives have different focuses in relation to the parties between which trust and cooperation is built. Some concentrate on building trust and cooperation between labour/producers and capital, whereas others also seek to promote cooperation with the state. Other initiatives attempt to build strong alliances among workers (qua workers) and producers (qua producers). In light of these points, we further disaggregate Category $\mathrm{C}$ into the following criteria:

- Promotion of coordination, communication and trust between labour/producers and capital

- Promotion of coordination, communication and trust between labour/producers, capital AND government

- $\quad$ Promotion of sustainable social alliances between labour/producer organisations 
Category D concerns ideational or ideological transformation regarding the perceived rights and responsibilities of business, workers, consumers and the state. Here we further disaggregate this category as follows:

- Challenging ideas relating to rights and responsibilities of business

- Challenging ideas relating to rights and responsibilities of workers/producers

- Challenging ideas relating to rights and responsibilities of consumers

- Challenging ideas relating to rights and responsibilities of states

These then are the concrete criteria we consider as we examine the various initiatives throughout the book, as a basis for evaluating their contributions to the project of 'globalising justice' at the level of institutional transformation. Individual authors do not work explicitly with these criteria, though these do constitute background considerations, and we invite readers to keep these criteria in mind as they read the individual chapters. We then revisit these criteria in our concluding synthesis in Chapter 20.

One significant consequence of the diversity of the approaches taken by different authors is that the evidence generated by the volume as a whole in relation to each of these evaluative criteria is somewhat uneven. In particular, many chapters have more to say about the processes of institutional change engendered by the operation of these governance initiatives than they do about ultimate outcomes (in terms of documented labour standards, welfare provision, and so on). This is certainly not true of all chapters, and we draw out findings regarding outcomes for individuals and communities where possible. However, much analysis does focus on the second and third dimensions, and this is reflected in the attention we give to these different dimensions in our concluding synthesis. 
Globalising social justice norms and the collaboration/confrontation debate

At the beginning of this chapter we highlighted the contrasting 'images' of more collaborative versus transformative or confrontational approaches to globalising justice within transnational economic relations. How then does examination of these broad evaluative criteria relate to debates around these approaches? The criteria established in the previous section equip us with tools to assess the ways in which initiatives are contributing to the broad goal of 'globalising justice'. But this book also seeks insight into the question of means. The justice initiatives we examine in this volume operate as vehicles of broader institutional change at the same time as they perform important social governance functions in their own right. Whether they adopt more collaborative or confrontational approaches, all the initiatives examined in this volume seek to bring about outcomes for individuals and communities that are more in line with the social justice norms they identify. Where they differ is in relation to both strategies and objectives in relation to broader features of institutional change.

The institutional focus of the criteria established above enables us to engage very directly with the question of how such institutional change is achieved. In particular, we are interested in examining the extent to which different initiatives tend to operate within and reinforce the terms of the prevailing system (via 'collaborative' approaches), or to challenge these prevailing terms (via more 'confrontational' or 'transformative' approaches). We consider the extent to which a given initiative (as a vehicle of institutional change) challenges the system by considering both its stated ends, and the means that it adopts. Generally speaking, a more transformative approach is more likely to: 
- Challenge the legitimacy of existing distributions of rights and duties (between workers/producers, businesses, consumers and governments) within the design of the system

- Challenge social power relations embedded within institutional arrangements, via pursuit of strategies that seek to shift underlying balances of social power

- Pursue change via working outside accepted rules and procedures associated with established institutions

At the other end of the spectrum, those seeking change 'within the terms of the system' are more likely to accept the legitimacy of prevailing distributions of roles and responsibilities (rights and duties) and/or prevailing power relations, and seek via established rules and processes - to promote desired social justice outcomes by enhancing the capacity of the institutional system as a whole to promote and protect these desired outcomes.

The different initiatives examined by this book combine these objectives and strategies in varying ways. Each initiative - as a vehicle of transformation - targets different features of the existing governance system, and also utilises different combinations of broadly 'collaborative' or 'confrontational' strategies in seeking to bring about institutional change of particular kinds. Thus, while the framing of this debate begins from the simple contrasting 'images' of collaborationist versus confrontational stances outlined above, our analysis also seeks to unbundle and disaggregate these overly tidy categories where necessary.

Together, the chapters that make up this volume present a very wide variety of views and canvass a broad range of issues and cases. All speak in some way to overarching debates about the objectives and strategies of these experiments in globalising justice, and their potential contribution to the broader project of re- 
embedding a globalising market economy within an emergent set of norms around the agenda of global social justice. This volume as a whole is presented as a contribution to this ongoing debate. 


\section{References}

Appelbaum, Richard. 2006 (draft). "Giant Retailers and Giant Contractors in China: Emergent Trends in Global Supply Chains." Working paper prepared for Princeton University Conference, Observing Trade: Revealing International Trade Networks March 9-11, 2006.

Armbruster-Sandoval, Ralph. 2005. Globalization and cross-border labor solidarity in the Americas : the anti-sweatshop movement and the struggle for social justice. New York ; London: Routledge.

Ayres, I and J Braithwaite. 1995. Responsive regulation: Transcending the deregulation debate. New York: Oxford University Press

Baby Milk Action. 2009. "Baby Milk Action website."

Beitz, Charles. 1983. "Cosmopolitan Ideals and National Sentiment." The Journal of Philosophy 80(10).

Beitz, Charles. 1999. "International Liberalism and Distributive Justice: A Survey of Recent Thought." World Politics 51(2).

Beitz, Charles. 2001. "Does Global Inequality Matter?" Metaphilosophy 32(1/2).

Bendell, JB. 2004. "Barricades and Boardrooms: A contemporary history of the corporate accountability movement." Geneva: UNSRID.

Blackett, Adelle. 2001-2002. "Global Governance, Legal Pluralism and the Decentered State: A Labor law Critique of Codes of Corporate Conduct." Indiana Journal of Global Legal Studies 8:401-448.

Blowfield, Michael. 2005. "Corporate Social Responsibility: reinventing the meaning of development?" International Affairs 81(3).

Blumberg, Paul. 1968. Industrial Democracy: The Sociology of Participation. London: Constable. 
Carroll, Archie. 1999. "Corporate Social Responsibility: Evolution of a Definitional Construct." Business and Society 38(3).

Coates, Ken. 2003. Workers' Control: Another World is Possible: Spokesman Books.

Collins, Hugh. 1990. "Independent Contractors and the Challenge of Vertical Disintegration to Employment Protection Laws." Oxford Journal of Legal Studies 10(3):353-380.

Cramme, Olaf and Patrick Diamond. 2009. Social Justice in the Global Age. Cambridge: Polity.

Crouch, Colin. 2005a. Capitalist Diveristy and Change: Recombinant Governance and Institutional Entrepreneurs. Oxford: Oxford University Press.

Crouch, Colin. 2005b. "Models of Capitalism." New Political Economy 10(4):439456.

Crouch, Colin and Wolfgang Streeck eds. 2006. The Diversity of Democracy: corporatism, social order and political conflict. Cheltenham, UK and Northhampton, MA: Edward Elgar.

Cumbers, Andres, Danny MacKinnon and Robert McMaster. 2003. "Institutions, Power and Space: Assessing the Limits to Institutionalism in Economic Geography." European Urban and Regional Studies 10(4).

Deyo, Frederic. 1989. Beneath the Miracle: Labour Subordination in the New Asian Industrialism. Berkeley: University of California Press.

Dicken, Peter. 2000. "A New Geo-economy." In The global transformations reader : an introduction to the globalization debate, eds. David Held and Anthony G. McGrew. Cambridge: Polity.

Doh, Jonathan. 2006. "Global Governance, Social Responsibility and corporate-NGO collaboration." In Transformations in global governance: implications for 
multinationals and other stakeholders, ed. Sushil Vachani. Cheltenham: Edward Elgar.

Fenwick, Colin , John Howe, Shelley Marshall and Ingrid Landau. 2008. "Labour and Labour Related Laws in Small and Micro Enterprises: Innovative Regulatory Responses." ed. SEED. Geneva: International Labour Organisation, .

Fox, Tom. 2004. "Corporate Social Responsibility and Development: In quest of an agenda." Development 47(3):29-36.

Friedman, Milton. 1970. "The Social Responsibility of Business is to Increase its Profits." In The New York Times Magazine. New York.

Gereffi, G and Olga Memedovic. 2003. "The Global Apparel Chain: What prospects for upgrading for developing countries?" http://www.inti.gov.ar/cadenasdevalor/ApparelUNIDOnew2Feb03.pdf.

Gereffi, Gary, John Humphrey and Timothy Sturgeon. 2005. "The governance of global value chains." Review of International Political Economy 12(1).

Gereffi, Gary and Frederick W. Mayer. 2004. "The Demand for Global Governance." Terry Sanford Institute of Public Policy Working Paper, Duke.

Giddens, Anthony. 1990. The Consequences of Modernity. Cambridge: Polity Press.

Gilson, Ronald, Charles Sabel and Robert Scott. 2009. "Contracting for Innovation: Vertical Disintegration and Interfirm Collaboration." Columbia Law Review 109.

Granovetter, Mark. 1985. "Economic Action and Social Structure: The Problem of Embeddedness." The American Journal of Sociology 91(3).

Hale, Angela and Jane Wills. 2005. Threads of Labour: Garment industry supply chains from the workers' perspective. Oxford: Blackwell. 
Hall, Peter A. 2007. "The Evolution of Varieties of Capitalism in Europe." In Beyond Varieties of Capitalism: conflict, contradictions and complementarities in the European economy, eds. Bob Hancke, Martin Rhodes and Mark Thatcher. Oxford: Oxford University Press.

Harrison, Ann and Jason Scorse. 2004. "Moving up or moving out? Anti-sweatshop activists and labour market outcomes." NBER Working Paper No. w10492(May 2004).

Harvey, David. 1990. The Condition of Post-Modernity: An Enquiry into the Origins of Cultural Change Oxford: Blackwell.

Harvey, David. 2006. The Spaces of Global Capitalism. London, New York: Verso.

Haufler, Virginia. 2001. A Public Role for the Private Sector: Industry SelfRegulation in a Global Economy. Washington, DC: Carnegie Endowment for International Peace.

Human Rights Council. 2007. "Business and Human Rights: Mapping International Standards of Responsibility and Accountability for Corporate Acts." In A/HRC/4/035: United Nations Human Rights Council.

Human Rights Council. 2008. "Promotion and Protection of all Human Rights, Civil, Political, Economic, Social and Cultural Rights, including the Right to Development; Protect, Respect and Remedy: A Framework for Business and Human Rights." In Report of the Special Representative of the Secretary General on the issue of human rights and transnational corporations and other business enterprises, John Ruggie: Human Rights Council.

ILO. 2002. "Decent Work and the Informal Economy, Report VI." In International Labour Conference, 90th Session.

ILO. 2005. "The Employment Relationship." ed. ILC. 
Jaffee, D. 2007. Brewing Justice: Fair Trade Coffee, Sustainability and Survival: University of California Press.

Jenkins, Rhys. 2005. "Globalization, Corporate Social Responsibility and poverty." International Affairs 81(3).

Jenkins, Rhys Owen, Ruth Pearson and Gill Seyfang. 2002. Corporate responsibility and labour rights : codes of conduct in the global economy. London: Earthscan.

Jessop, Bob. 2001a. "Regulationist and Autopoieticist Reflections on Polyani's Account of Market Economies and the Mark." New Political Economy 6(2):213-232.

Jessop, Bob. 2001b. "The Social Embeddedness of the Economy and its Implications for Economic Governance." http://www2.cddc.vt.edu/digitalfordism/fordism_materials/jessop2.htm.

Jessop, Bob. 2002. The Future of the Capitalist State. Cambridge: Polity Press.

Keck, Margaret E. and Kathryn Sikkink. 1998. Activists beyond borders : advocacy networks in international politics. Ithaca, N.Y. ; London: Cornell University Press.

Keohane, Robert ed. 2002. Power and Governance in a Partially Globalized World: Routledge.

Kirton, John J. and Michael J. Trebilcock eds. 2004. Hard choices, soft law : voluntary standards in global trade, environment, and social governance. London: Ashgate.

Korten, David C. 1995. When Corporations Rule the World. London: Earthscan.

Krippner, G, Mark Granovetter, F Block, N Biggart, T Beamish, Y Hsing, G Hart, G Arrighi, M Mendell, J Hall, M Burawoy, S Vogel and S O'Riain. 2004. 
"Polanyi Symposium: a conversation on embeddedness." Socio-Economic Review 2.

Kuper, Andrew ed. 2005. Global Responsibilities: Who Must Deliver on Human Rights? New York: Routledge.

Low, William and Eileen Davenport. 2005. "Postcards from the Edge: Maintaining the 'Alternative' Character of Fair Trade." Sustainable Development 13.

Macdonald, Kate 2007. "Public accountability within transnational supply chains: A global agenda for empowering southern workers?" In Forging Global Accountabilities: Participation, Pluralism and Public Ethics, eds. Alnoor Ebrahim and Edward Weisband. Cambridge: Cambridge University Press.

Marshall, Shelley. 2006. "An Exploration of Control in the Context of Vertical Disintegration, and Regulatory Responses." In Labour Law and Labour Market Regulation: Essays in the Construction, Constitution, and Regulation of Labour Markets and Work Relationships, eds. Chris Arup, John Howe, Richard Mitchell and Anthony O'Donnel. Sydney: Federation Press.

Marshall, T. H. . 1950. Citizenship and social class and other essays. Cambridge: Cambridge University Press.

McAdam, Doug, Sidney Tarrow and Charles Tilly. 2001. Dynamics of Contention Cambridge, UK: Cambridge University Press.

McBarnet, Doreen. 2007. "Corporate social responsibility beyond law, through law, for law: the new corporate accountability." In The New Corporate Accountability: Corporate Social Responsibilty and the Law, eds. Doreen McBarnet, Aurora Voiculescu and Tom Campbell. Cambridge: Cambridge University Press. 
McBarnet, Doreen, A Voiculescu and Tom Campbell eds. 2007. The New Corporate Accountability: Corporate Social Responsibility and the Law. Cambridge: Cambridge University Press.

McCormick, Dorothy and Hubert Schmitz. 2002. "Manual for value chain research on homeworkers in the garment industry." Sussex: Institute of Development Studies, Women in Informal Employment Globalizing and Organizing.

Miller, David. 1991. "Theories of Social Justice." British Journal of Political Science 21(3):371-391.

Miller, David. 1997. "Equality and Justice." Ratio X(3).

Miller, David. 1999. Principles of social justice. Cambridge, Mass.: Harvard University Press.

Murray, Douglas, Laura Raynolds and Peter Leigh Taylor. 2003. "One Cup at a Time: Poverty Alleviation and Fair Trade Coffee in Latin America." www.colostate.edu/Depts/Sociology/FairTradeResearchGroup: Colorado State University.

Murray, Jill. 2001. "The Sound of One Hand Clapping? The "Ratcheting Labour Standards" Proposal and International Law." Australian Journal of Labour Law 14.

Newell, Peter and George Frynas. 2007. "Beyond csr? Business, poverty and social justice: an introduction " Third World Quarterly: Special Issue on 'Beyond CSR? Business, Poverty and Social Justice’ 28(4):669 - 681

O'Brien, Robert. 2000. "Workers and world order: the tentative transformation of the international union movement." Review of International Studies 26:533-555. 
O'Brien, Robert, Anne Marie Goetz, Jan Aart Scholte and Marc Williams. 2000. Contesting Global Governance: Multilateral Economic Institutions and Global Social Movements. Cambridge: Cambridge University Press.

O'Riain, Sean. 2000. "States and Markets in an Era of Globalization." Annual Review of Sociology 26:187-123.

Parker, Christine. 2002. The Open Corporation: Effective Self-regulation and Democracy. Cambridge: Cambridge University Press.

Parker, Christine E. 2007. "Meta-Regulation: Legal Accountability for Corporate Social Responsibility. ." ed. University of Melbourne Legal Studies Research Paper.

Pateman, Carole. 1970. Participation and democratic theory. Cambridge: Cambridge University Press.

Pogge, Thomas ed. 2001. Global justice. Oxford: Blackwell.

Pogge, Thomas. 2002. World Poverty and Human Rights: Cosmopolitan Responsibilities and Reforms. Cambridge: Polity Press.

Polanyi, Karl. 1944. The Great Transformation: The Political and Economic Origins of Our Time. Boston: Beacon Press.

Raynolds, L, D Murray and J Wilkonson. 2007a. Fair Trade: The challenges of transforming globalization. London and New York: Routledge.

Raynolds, Laura. 2002a. "Consumer/Producer Links in Fair Trade Coffee Networks." Sociologia Ruralis 42(4).

Raynolds, Laura. 2002b. "Poverty Alleviation Through Participation in Fair Trade Coffee Networks: Existing Research and Critical Issues." http://www.colostate.edu/Depts/Sociology/FairTradeResearchGroup/doc/rayb ack.pdf. 
Raynolds, Laura, Douglas Murray and Peter Leigh Taylor. 2004. "Fair Trade Coffee: Building Producer Capacity Via Global Networks." Journal of International Development 16.

Raynolds, Laura, Douglas Murray and John Wilkinson eds. 2007b. Fair Trade: The challenges of transforming globalization. New York: Routledge.

Richter, Judith. 2001. Holding Corporations Accountable: Corporate Conduct, International Codes and Citizen Action. London and New York: Zed Books.

Ross, Andrew. 1997. No sweat : fashion, free trade, and the rights of garment workers. New York; London: Verso.

Ruggie, John. 1982a. "International Regimes, Transactions and Change: Embedded Liberalism in the Postwar Economic Order." International Organization 36(2).

Ruggie, John ed. 2008. Embedding Global Markets: An enduring challenge: Ashgate.

Ruggie, John Gerald. 1982b. "International Regimes, Transactions, and Change: Embedded Liberalism in Postwar Economic Order." International Organization 36(2).

Ruggie, John Gerald. 2003. "Taking Embedded Liberalism Global: The Corporate Connection." In Taming Globalization: Frontiers of Governance, eds. David Held and Mathias Koenig-Archibugi. Cambridge: Polity Press.

Sassen, Saska. 2002. "The state and globalisation." In The emergence of private authority in global governance, eds. Rodney Bruce Hall and Thomas J. Biersteker. Cambridge: Cambridge University Press.

Sassen, Saskia. 2003. "The Participation of States and Citizens in Global Governance." Indiana Journal of Global Legal Studies 10(5:1).

Sen, Amartya. 2009. "Capitalism Beyond the Crisis." The New York Review of Books 56 (5). 
Smith, Sally and Stephanie Barrientos. 2005. "Fair Trade and Ethical Trade: Are There Moves Towards Convergence?" Sustainable Development 13.

Starr, A. 2000. Naming the enemy: Anti-corporate Movements Confront Globalization. London: Zed Books.

Stewart, Frances. "Macro-Micro Interactions in a Dynamic Context." In Group Behaviour and Development: Is the Market Destroying Cooperation?, eds. J Heyer, Frances Stewart and Rosemary Thorp. Oxford: Oxford University Press.

Streeck, Wolfgang. 2009. Re-Forming Capitalism: Institutional Change in the German Political Economy. Oxford, UK: Author's copy, Forthcoming, Oxford Univesity Press.

Tarrow, S. 1994. Power in movement: social movements, collective action and politics. Cambridge: Cambridge University Press.

Utting, Peter. 2005. "Rethinking Business Regulation: From Self-Regulation to Social Control." In UNRISD Technology Business and Society Programme Paper Number 15. Geneva: UNRISD.

Utting, Peter. 2006. "Corporate Social Responsibility and Equality." In Summary of presentation for the UNRISD - Sida/SAREC Workshop on Social Policy and Equality, 21-22 February 2006, Buenos Aires, Argentina. Geneva: United Nations Research Institute for Social Development.

Vitt, Judith. 2007. "From conflict to collaboration: NGOs and businesses." CSR Asia Weekly

3(51):http://www.systain.de/Website/Downloads/Dokumente/csrasiaweeklyvo 13week51.pdf. 
Vogel, David. 2005. The market for virtue : the potential and limits of corporate social responsibility. Washington, D.C.: Brookings Institution Press.

Wade, Robert. 2008. "Financial Regime Change?" New Left Review 53(SeptemberOctober).

Wood, Ellen Meiksins 2002. The Origins of Capitalism: A Longer View. London: Verso.

Zerk, Jennifer. 2006. Multinationals and Corporate Social Responsibility. Cambridge: Cambridge University Press. 


\section{University Library}

\section{- M M I N E R VA A gateway to Melbourne's research publications}

Minerva Access is the Institutional Repository of The University of Melbourne

Author/s:

Macdonald, K;Marshall, S

Title:

Social governance in a global economy: Introduction to an evolving agenda

Date:

2010-12-01

Citation:

Macdonald, K. \& Marshall, S. (2010). Social governance in a global economy: Introduction to an evolving agenda. Fair Trade, Corporate Accountability and Beyond: Experiments in Globalizing Justice, (1), pp.3-33. Ashgate.

Persistent Link:

http://hdl.handle.net/11343/91892 